DOI: $10.20472 / E S .2016 .5 .3 .002$

\title{
THE EFFECT OF BANK COMPETITION ON THE EFFECTIVENESS OF THE INTEREST RATE CHANNEL OF MONETARY POLICY TRANSMISSION
}

\author{
PATRICK MUMBI CHILESHE, OLUSEGUN AYODELE AKANBI
}

\begin{abstract}
:
This study investigates the effect of bank competition on the interest rate pass-through in Zambia. Specifically, the study investigates whether lack of competition dampens the transmission of monetary policy changes to retail rates as well as its effects on the level of interest rates. The study developed a theoretical model based and tested it using dynamic panel data methods. Furthermore, the study used bank level data covering the period Q1 1998 to Q2 2015. The authors used two measures of bank competition namely $\mathrm{HHI}$ and Lerner Index The results from the study indicated that higher competition enhances the transmission of monetary policy changes to retail rates. In addition, results indicated that there is positive relationship between a measure of competition and lending rates charged by commercial banks. From a policy perspective, these results imply that there is need for more financial reforms aimed at enhancing competition in the banking sector in order to lower lending rates as well as enhancing monetary policy effectiveness.
\end{abstract}

\section{Keywords:}

HHI, Boone Index, Lerner Index, Interest rate pass-through, monetary policy, Panel Data

JEL Classification: E43, G21, L22

\section{Authors:}

PATRICK MUMBI CHILESHE, Bank of Zambia, , Zambia, Email: pchileshe@boz.zm

OLUSEGUN AYODELE AKANBI, University of South Africa, South Africa, Email: akanboa@unisa.ac.za

\section{Citation:}

PATRICK MUMBI CHILESHE, OLUSEGUN AYODELE AKANBI (2016). The effect of Bank competition on the effectiveness of the Interest Rate Channel of Monetary Policy Transmission. International Journal of Economic Sciences, Vol. V(3), pp. 10-32., 10.20472/ES.2016.5.3.002 


\subsection{Introduction}

Over the years a lot of research has been done on monetary policy transmission with a view understanding its effect on the real sector and the channels through which this process occurs. These studies have shown that there are differences in the transmission mechanism of monetary policy between the developed and developing countries (Mishra et al., 2010; Sims, 1992). Specifically, it has been shown that the effectiveness of monetary policy in influencing real variables is weaker in developing compared to developed countries. In addition, the channels of monetary policy working in developing countries differ from those operational in developed economies (Tahir, 2012; Mishra et al., 2010). A number of reasons have been attributed to these differences among them larger size of the informal market; inefficiency in the capital markets; poorly developed money and interbank markets; and low competition in the commercial banking sector (Mishra et al., 2010). Although these features are common in developing countries there is little research dedicated to uncovering their effects on monetary policy transmission process. It is against this background that this study investigates the effect of bank competition or concentration on the interest rate passthrough in Zambia which is the first stage in monetary policy transmission process.

This study utilised panel data methods to investigate the effect of bank market power or concentration on the monetary policy transmission in Zambia, specifically the interest rate pass-through. Results indicate that increased competition among commercial helps to lower commercial bank lending rates in both the short- and longrun and vice versa. Most importantly for this study, results show that low of competition among commercial banks hinders the transmission of monetary policy changes to retail rates.

The rest of the paper is organised as follows: Section 2 provides a review of relevant literature followed by a discussion of the methodology in section 3; empirical results are provided in section 4 while section 5 concludes.

\subsection{Review of Literature}

Empirical studies on the role of bank competition play in the monetary transmission process have been carried out for decades in the developed economies, however, there is little or no research from developing country worse so in the sub-Saharan Africa. In this regard, much of the empirical evidence we present in this section is mostly from the developed economies and very little from developing countries, and one from the sub-Saharan Africa.

Empirical studies using data from United States of America (USA) are in two categories: those investigating the effect of bank concentration/competition on the bank lending channel (Adams and Amel, 2005; Brissmiss et al., 2013; Severe, 2011) and the interest rate pass-through (Meir-y-Teran, 2012). Using panel data methods and Herfindahl-Hirschman Index $(\mathrm{HHI})$, Boone Index as well as the Lerner Index as measures of competition, these studies conclude that higher low competition reduces 
the effectiveness of monetary policy transmission. Specifically, Adams and Amel (2005) find that higher market concentration reduces the sensitivity of bank lending to changes in the federal funds rate. In addition, they find the response of small loans in concentrated markets to an increase in the monetary policy rate to be almost zero in concentrated markets. Using a similar method to Adams and Amel (2005), Severe (2011) investigates the effect regional bank competition in the USA on bank lending and finds that lack of competition not only raises interest rates but also dampens monetary policy transmission. Brissimiss, Delis and losifidi (2013) investigates the effect of bank market power on bank lending channel using the Lerner and Boone Indices as measures of competition and find that the potency of the relationship between policy and bank credit weakens for banks that have even moderate levels of market power. Specifically, they find that only about $1 \%$ higher market power relative to that of an average bank in their sample is sufficient to completely buffer the negative effect of contractionary monetary policy on bank lending and risk taking. Finally, Meir$\mathrm{y}$-Teran (2012) uses the $\mathrm{HHI}$ to study the effect of bank concentration on the interest pass-through and finds that lower bank competition reduces the effectiveness of the interest rate pass-through. Specifically, they find that the short- and long-run passthrough is high in regions where there is high competition among banks.

Another strand of empirical literature on the role of bank competition on monetary policy transmission comes from the Euro area (Leroy and Lucotte, 2014; Fingacova et al., 2013; Brissmiss et al., 2013; Leuwenstein et al., 2006). All these studies utilise panel data methods and non-structural indicators of market power as measures of competition (Boone and Lerner Index). In general, empirical results of studies in the euro area indicate that existence of strong competition among banks helps to improve the transmission of monetary policy shocks. A study by Leroy and Lucotte (2014) uses the Lerner Index as a measure of competition and find that interest rate spreads are lower under stronger bank competition and that strong bank competition enhances short- and long-term pass-through. At the same time stronger bank competition lowers retail rates. Leuwenstein et al. (2006) uses the Boone Index and find that higher competition affects the interest rate pass-through in a similar way. Studies by Brissmiss et al. (2013) and Fingacova et al. (2013) uses the Lerner Index to study the effect of bank competition on the bank lending channel and come to the same conclusion. Specifically, they find that increased competition helps to accelerate extension of credit by commercial banks. In addition, they find that increased bank competition enhances the effectiveness of monetary policy (i.e response of credit to monetary policy).

In emerging and developing countries, the scant empirical literature available reaches similar conclusions as those done in developed economies (Deriantino, 2009; Sanders and Kleimeir, 2004). Deriantino (2009) develops a theoretical and empirical model and tests it using banking sector panel data from Indonesia for the period 2001-2012. Using the Lerner Index as a measure of competition, results of the study shows that banking competition affects the transmission of monetary policy changes in the loan 
market and not the deposit market. Specifically, they find that a more competitive bank is more responsive to changes in policy changes; implying bank competition may enhance effectiveness of monetary policy transmission in loan market. Hence, the study concludes that improving competition in the banking system helps to enhance the effectiveness of monetary policy. On the other hand Sanders and Kleimeir (2004) investigates the effect of bank competition on the bank lending channel in Eurozone emerging economies of Czech Republic, Hungary, Poland, Hungary, Lithuania, Latvia, Slovakia, Estonia and Slovenia using panel data for the period 1993 to 2003. Their study uses 3-firm concentration ratio as a measure of competition and Vector Autoregressive methods that allow for time varying parameter. Their empirical results indicate that a more competitive banking environment increases the speed of the passthrough. Hence, they conclude that competition in the banking is a key ingredient in improving the effectiveness of monetary policy transmission.

From the African region, Mangwengwende, Chizara and Neil (2011) investigate the relevance of bank concentration in the interest rate pass-through of four Sub-Saharan African countries of Botswana, Nigeria, South Africa and Zambia. This study uses two simple approaches to uncover the role bank competition plays in interest rate passthrough. In the first approach they estimate the average bank concentration in each of the four countries and compare the interest pass-through in each country to evaluate whether countries with the highest concentration have the weakest interest rate passthrough. The second approach involves tracing the dynamics of the interest rate passthrough and bank concentration overtime using an 8-year rolling window. Their model includes lending and deposit rates, and a central bank rate. Using a 3-firm concentration ratio as a measure of competition they find strong evidence of cointegration in South Africa and Zambia while Nigeria and Botswana has a weak one for both lending and deposit rates. However, the pattern of concentration does not seem to be related to the existence of co-integration between lending rates or deposit rates and the monetary policy variable. They find that South Africa, whose bank concentration is marginally lower than Botswana, has the strongest and Botswana has the weakest co-integration results while Nigeria with the lowest bank concentration level also has stronger co-integration results. Further, they find that Botswana with the highest level of bank concentration has the lowest adjustment for both deposit and lending rates. In addition, although Nigeria has the lowest concentration it does not have the highest speed of adjustment. Specifically, following a disturbance to the equilibrium it takes 2.6 months and 1.7 months in Botswana for deposit and lending rates return to equilibrium, it takes 0.7 months and 0.5 months respectively in South Africa. In terms of the magnitude of adjustment they find that there is a positive relationship between concentration and short run adjustment of deposit rates and though no clear evidence is found for lending rates. They find that Nigeria with the lowest concentration has smallest response and it is highest in South Africa with highest concentration. Using these results they conclude that there is evidence to show that bank concentration affects the interest rate channel. 


\subsection{Methodology}

\subsection{Theoretical Framework}

The theoretical framework presented in this section follows in the Monti-Klein model of imperfect bank competition. Specifically, we assume that we have $\mathrm{N}(i=$ $1,2,3, \ldots, N)$ banks that compete in cournot type oligopolistic market. In our model, banks are financial intermediaries that buy funds known as deposits at lower rates from net savers and lend them for a profit to deficit economic agents (Freixas and Rocha, 1997; Severe, 2012; Muller-Spahn, 2009). The set of economic agents that seek funds from bank include households and firms in form of loans, the government via securities, and fellow commercial banks via the interbank market.

In this regard, the balance sheet of a bank consist of one liability deposits (assuming no initial equity is allowed for lending), $D_{i}$; while assets include funds placed on the interbank $\left(E_{i}\right)$, Loans $\left(L_{i}\right)$, and government Securities $\left(G_{i}\right)$. That is;

$$
D_{i}=E_{i}+G_{i}+L_{i} \ldots \ldots \ldots \ldots \ldots 3.1
$$

Assuming that return to funds placed on the interbank market is $r_{E}$ while the return on securities is $r_{G}$, and banks charge an interest rate of $r_{L}$ to loans it extends to the public. Furthermore, banks pay a deposit rate $\left(R_{i}\right)$ to attract deposits from net savers. In addition, the bank incurs operational costs for maintaining its loan and deposit books which is a function its loan and deposit portifolio. Therefore, the net return or profit of an individual bank is given by;

$$
\pi_{i}=L_{i} r_{i L}+E_{i} r_{E}+G_{i} r_{G}-D_{i} R_{i}-C_{i}\left(D_{i}, L_{i}\right) \ldots \ldots \ldots \ldots \ldots \ldots .2
$$

We assume that the inverse demand function for loans is a negative function of loan rate in the market $\left(L=L_{1}+L_{2}+L_{3}+\cdots+L_{N}\right)$. The inverse demand function is given by;

$$
r_{i L}=r(L, \varphi) ; r^{\prime}(.)<0 \ldots \ldots \ldots \ldots 3.3
$$

Where $\varphi$ represent bank and market specific characteristics which affect the demand for loans. On the other hand, deposits are a positive function of the deposit rate;

$$
D_{i}=D\left(R_{i}, \varnothing\right) ; D^{\prime}(.)>0 \ldots \ldots \ldots \ldots 3.4
$$

Furthermore, we assume that the interbank market is perfectly competitive such that individual banks are price takers. In addition, we assume that the supply of securities is perfectly inelastic (Mueller-Spahn, 2009; Severe, 2011). Therefore, combining equations 3.1-3.4 the profit maximising problem of a particular bank is given by;

$$
\max _{L_{i}, E_{i}, G_{i}, D_{i}} \pi_{i}=L_{i} r(L, \varphi)+E_{i} r_{E}+G_{i} r_{G}-D\left(R_{i}, \emptyset\right) R_{i}-C_{i}\left(D_{i}, L_{i}\right)
$$

Subject to

$$
D_{i}=E_{i}+G_{i}+L_{i} \ldots \ldots \ldots . . .3 .5
$$


The first order conditions for solving the above optimisiation problem using the Langrangian method is given by;

$$
\begin{gathered}
\frac{\partial \mathcal{L}}{\partial L_{i}}=r(L, \varphi)+r^{\prime}(L, \varphi) * L_{i}-\lambda-C_{i}^{\prime}\left(D_{i}, L_{i}\right)=0 \ldots \ldots .6 \\
\frac{\partial \mathcal{L}}{\partial E_{i}}=r_{E}-\lambda=0 \ldots \ldots \ldots 3.7 \\
\frac{\partial \mathcal{L}}{\partial E_{i}}=r_{G}-\lambda=0 \ldots \ldots \ldots 3.8 \\
\frac{\partial \mathcal{L}}{\partial D_{i}}=-R_{i}-C_{i}^{\prime}\left(D_{i}, L_{i}\right)+\lambda=0 \ldots \ldots \ldots 3.9
\end{gathered}
$$

Using equations 3.6-3.8, we obtain the following optimal condition;

$$
r(L, \varphi)+r^{\prime}(L, \varphi) * L_{i}-C_{i}^{\prime}\left(D_{i}, L_{i}\right)=r_{E}=r_{G} \ldots \ldots \ldots 3.10
$$

Equation 3.10 shows that in maximising their profits banks choose to lend until the net marginal revenue from a loan is equal to the opportunity cost of investing in other assets: the interbank market rate or the risk-free return on government securities. In other words it states that banks lend until the net return on the margin from loans is equal to the opportunity cost; risk free rate or the interbank market rate.

Using equations 3.7-3.9 we obtain the optimal condition for the deposite rate is given by;

$$
R_{i}+C_{i}^{\prime}\left(D_{i}, L_{i}\right)=r_{E}=r_{G} \ldots \ldots . .3 .11
$$

Equation 3.11 shows that in raising funds from depositors banks ensure that the cost of managing funds is just equal to the risk free return that they can get on the risk free government securities. In other words, in setting the deposit rate banks look at the risk free return and then reduce it by the amount of cost involved in managing these deposits.

\subsubsection{Comparative Statics}

Using equation 3.10, here we show that a commercial banks loan market rate response to monetary policy stance depends on the level of competition prevailing in the banking sector. Solving equation 3.10 for the optimal loan rate we obtain;

$$
r^{*}(L, \varphi)=-r^{\prime}(L, \varphi) * L_{i}+C_{i}^{\prime}\left(D_{i}, L_{i}\right)+r_{E} \ldots \ldots . .3 .12
$$

Multiplying equation 3.12 by L/L throughout, we get;

$$
\begin{array}{r}
r^{*}(L, \varphi)=-r^{\prime}(L, \varphi) * \frac{L_{i}}{L} L+C_{i}^{\prime}\left(D_{i}, L_{i}\right)+r_{E} \\
r^{*}(L, \varphi)=-r^{\prime}(L, \varphi) * s_{i} L+C_{i}^{\prime}\left(D_{i}, L_{i}\right)+r_{E} \ldots \ldots \ldots
\end{array}
$$


Where $s_{i}$ is bank $i$ 's share in the total loan market. Multiplying both sides by market and then aggregating over all firms, we get;

$$
r^{*}(L, \varphi)=-r^{\prime}(L, \varphi) * H H I * L+C_{i}^{\prime}\left(D_{i}, L_{i}\right)+r_{E} \ldots \ldots \ldots . . .3 .14
$$

Equation 3.14 shows that the loan rate is an increasing function of the HirschmanHerfindahl Index $(\mathrm{HHI})$. In other words, an increase in market concentration or falling competition increase the banks mark-ups. Specifically, the first derivative of loan rate with respect to the $\mathrm{HHI}$ is given by;

$$
\frac{\partial r^{*}(L, \varphi)}{\partial H H I}=-r^{\prime}(L, \varphi) * L>0 ; \text { since } r^{\prime}(L, \varphi)<0 \ldots \ldots \ldots 3.15
$$

Furthermore, if firms are equally sized then; $H H I=1 / N$ which imply that;

$$
r^{*}(L, \varphi)=-r^{\prime}(L, \varphi) * \frac{L}{N}+C_{i}^{\prime}\left(D_{i}, L_{i}\right)+r_{E} \ldots \ldots \ldots . . .16
$$

From this, it can be seen that in perfect competition where $N \rightarrow \infty$ the loan intermediation rate equal their respective marginal costs. As the banking sector, however, becomes oligopolistic and $\mathrm{N}$ gets smaller, the loan intermediation margin rises (since $\left.r^{\prime}(L, \varphi)<0\right)(\operatorname{Lim}, 2001)$.

Furthermore, using equation 3.16 we can get the response of loans to monetary policy shock as a negative function of the $\mathrm{HHI}$;

$$
\frac{\partial L}{\partial r_{E}}=\frac{1}{H H I * r^{\prime}(L, \varphi)}<0 \ldots \ldots \ldots \ldots 3.17
$$

The above equation shows that the higher is the $\mathrm{HHI}$ the lower is the response of total loans to monetary policy shocks. This implies the level of market competition in the banking sector reduces the effectiveness of monetary policy. or put in another way the higher is the market power yielded by a firm the lower they are likely to respond to monetary policy shocks.

Multiplying equation 3.14 by $r(L, \varphi) / r(L, \varphi)$ throughout and then re-arranging will give;

$$
r^{*}(L, \varphi)=- \text { Lerner } * r^{*}(L, \varphi)+C_{i}^{\prime}\left(D_{i}, L_{i}\right)+r_{E} \ldots \ldots . .3 .18
$$

Since Lerner Index $=\frac{1}{\varepsilon}$, using equation 6.41 we can get the response of bank's lending rate rate to monetary policy rate as;

$$
\frac{\partial r^{*}(L, \varphi)}{\partial r_{E}}=\frac{1}{1+\text { Lerner }}>0 \ldots \ldots . . .3 .19
$$

The above comparative static indicates that commercial banks increases their interest rates in response to monetary policy tightening. However, that the extent of that response depends on amount of market power that a bank has. Specifically, the higher 
is the market power the bank holds the lower is the size of the response of lending rates to monetary policy.

Finally, equation 3.14 which is the optimal lending rate also describe a fundamental relationship between policy rates (risk free rate and the interbank rate) and the lending rate. In simple linear system equation 3.14 can written as;

$$
r_{L}=\alpha+\beta r_{i} \ldots \ldots \ldots . . .3 .20
$$

$\alpha$ can be seen as constant loan intermediation margins, whereas $\beta$ measure the effect of a change in the market rate on the retail rate.

\subsection{Empirical model and Estimation strategy}

In 3.1 a theoretical model was presented which try to give relationships among lending rates, interbank rate, bank competion and concentration. Many studies that have analysed the effect of bank competition exclusively use concentration measures such as the $\mathrm{HHI}$ to proxy competition among banks. However, new evidence from industrial economics literature questions the suitability of such measures (Leuwensteijn et al.,2006). Leunvensteijn et al. (2006) note that although the traditional interpretation is that concentration in an industry erodes competition, both concentration and competition maybe increasing when competiting forces are consolidating. For example, if inneficient firms are taken over by more efficient ones, competition may increase while concentration is also rising. In addition, the $\mathrm{HHI}$ suffers from a serious weakness in that it tends to be higher in small countries as a result of the small nature of these economies. Hence, to circumvent these criticisms we also use the Lerner Index, in addition to the HHI, to check the robustness of our results. Since the Lerner index is a bank specific measure of competition it is only necessary that we utilise the panel data methods to uncover the effect of competition in the banking system on monetary policy transmission. Furthermore, the available banking sector prudential data for Zambia is only available from January 1998 making time series analysis difficult.

The estimated model has lending rate as the dependent variables while bank concetration/market power, capital adequacy ration (CAR), Liquidity ratio and policy rate (Interbank rate and 3-month TB rate) are the independent variables. We estimate two models: One shows how changes in bank concentration overtime alters the response of banks to monetary policy; while the second one shows how differences in the market power of a particular bank affects its response to monetary policy stance. In this regard, the reduced take the form:

$$
\begin{gathered}
r_{i t}=\alpha_{i}+\beta_{1} r_{t E}+\beta_{2} H_{H I}+\beta_{3} r_{E} * H H I_{t}+\omega X_{i t} \\
r_{i t}=\alpha_{i}+\beta_{1} r_{E}+\beta_{2} \text { Lerner }_{i t}+\beta_{3} r_{E} * \text { Lerner }_{i t}+\omega X_{i t} \ldots \ldots 3.21
\end{gathered}
$$


In the two models in 3.21, $r_{L i t}$ is the lending rate for bank $i$ at time $t, r_{t E}$ is the Interbank money market rate or 3-month TB rate at time t, or monetary policy stance at time $t$, and $\mathrm{HHI}_{t}$ is the Herfindahl-Hirschman Index at time t while the Lerner $_{i t}$ is a lerner index for bank $i$ in time $t$. $\boldsymbol{X}_{i t}$ is a vector of bank specific explanatory variables. The theoretical framework presented above predicts that $\beta_{1}>0$ while $\beta_{2}>0$. Specifically, an increase in the interbank rate will cause banks to increase their lending rates while lower competition will cause interest margins to be higher. Furthermore, from equations 3.21 above, the coefficient on the interaction term, $\beta_{3}$, determines if changes in bank market competition alters the response of banks to monetary policy changes. If the presence of market concentration dampen monetary policy, then the interaction term should mitigate that coefficient, or $\beta_{3}<0$.

Available literature shows that most time series data tend to be non-stationary in nature. Infact much of this available literature seems to suggest that much of financial time series data tend to be integrated of order one, I(1) (Onunogbo, 2012; Leroy and Lucotte, 2014; Mojon, 2000;Sander and Kleimeir,2004; Liu et al., 2006). Hence, estimating equation 3.21 above using OLS methods would produce spurrious results. Spurrious regression results would be avoided by transforming equation 3.21 into differences, as shown below:

$$
\begin{array}{r}
\Delta r_{L i t}=\alpha_{i}+\beta_{1} \Delta r_{E}+\beta_{2} * \Delta H H I_{t}+\beta_{3} \Delta r_{E} * \Delta H H I_{t}+\boldsymbol{\omega} \Delta \boldsymbol{X}_{i t} \\
\Delta r_{L i t}=\alpha_{i}+\beta_{1} \Delta r_{E}+\beta_{2} * \Delta \text { Lerner }_{i t}+\beta_{3} \Delta r_{E} * \Delta \text { Lerner }_{i t}+\boldsymbol{\omega} \Delta \boldsymbol{X}_{i t} \ldots \ldots
\end{array}
$$

Although estimating equation 3.22 by OLS would help to circumvent spurrious results it would also loose the long-run relationship among the variables. Hence, to capture the long run relationship among the variables we include an error correction term (ECM) in our models. Including the ECM term in our model transforms equation 3.22 into:

$$
\begin{gathered}
\Delta r_{L i t}=\alpha_{0}+\beta_{1} \Delta r_{E}+\beta_{2} * \Delta H H I_{t}+\beta_{3} \Delta r_{E} * \Delta H H I_{t}+\boldsymbol{\omega} \Delta \boldsymbol{X}_{\boldsymbol{i t}}+\boldsymbol{\gamma} \boldsymbol{E C M}_{\boldsymbol{t}-\mathbf{1}} \\
\Delta r_{L i t}=\alpha_{0}+\beta_{1} \Delta r_{E}+\beta_{2} * \Delta \text { Lerner }_{i t}+\beta_{3} \Delta r_{E} * \Delta \text { Lerner }_{i t}+\boldsymbol{\omega} \Delta \boldsymbol{X}_{\boldsymbol{i t}}+\boldsymbol{\gamma} \boldsymbol{E C M}_{\boldsymbol{t}-\mathbf{1} \cdots 3.23}
\end{gathered}
$$

To uncover the effects of bank competition on the interest channel in Zambia, we utilise panel data methods. In panel data, a choice has to be made between the use of the fixed and random effects models. Fixed effects models assume that the unobserved individual effects are correlated withthe variables included in the while the random effects model does not (Hansen, 2002, p.135). This is because a choice of either fixed or random effect model has its own limitations. For example, Greene (2004, p.301) notes that fixed effects model is costly because it leads to loss of degrees of freedom compared to the random effects model. However, the fixed effects model has one important advantage over the random effects model. This is because there is little justification in treating the unboserved individual effects to be uncorrelated with the 
other variables as in the random effects and hence the random effects may suffer from inconsitency due to this correlation. Hence to decide on which of the approach to estimate we use the Hausman's Specification test outlined below.

\subsubsection{Specification Tests}

\section{Hausman's Specification Test}

The Hausman's specification test was devised by Hausman (1978). The Hausman's Specification Test is designed to detect violation of the random effects modelling assumption that the explanatory variables are orthagonal to the unit effects (Clark and Linzer, 2012). If there is no correlation between the independent variables and the unit effects, then estimates of $\beta_{i}$ 's in the fixed effects model $\left(\beta_{F E}\right)$ should be simillar to those estimated by the random effects model $\left(\hat{\beta}_{R E}\right)$. The Hausman test statistic, $\mathrm{H}$, is a measure of the difference between the two estimates:

$$
H=\left[\hat{\beta}_{R E}-\hat{\beta}_{F E}\right]^{\prime}\left[\operatorname{Var}\left(\hat{\beta}_{R E}\right)-\operatorname{Var}\left(\hat{\beta}_{F E}\right)\right]\left[\hat{\beta}_{R E}-\hat{\beta}_{F E}\right] \ldots \ldots 3.24
$$

Under the null hypothesis of no correlation, the $\mathrm{H}$ statistic is chi-square distributed with degree of freedom equal to the number of parameter estimates. Hence, if the null hypothesis of no correlation is rejected then we can conclude that the correct specification is the fixed effects model and vice-versa. However, if we fail to reject the null hypothesis it does not necessarily imply that the random effects model is free from bias (Clark and Linzer, 2012).

\section{Panel Unit Root Test}

Pooled time series data, just like univariate time series, tend to exhibit a time trend and hence they are most likely to be non-stationary; that is they have mean, variance and covariances that depend on time (Greene, 2012; p.323; Ramirez, 2006). Engel and Granger (1987) showed that using non-stationary time series in an OLS regression produces misspecified models and most likely spurious results. Specifically, regression results tend to produce very high performance statistics such as high $\mathrm{R}^{2}$ and very high t-statistics which could lead investigators to comit Type error at a high rate.

Although stationarity tests have been commonly used on univarite time series data, researcher have developed panel unit root tests. Popular among them include is Levin, Lin, Chu (2002); the Hadri test (1999); and Im, Pessaran, Shin (2003). All these tests have proved to be more powerful than univariate unit root tests(Ramirez,2006). In this study we employ the panel unit root test developed by Im, Pessaran, Shin (2003) hereafter referred to as the IPS. The IPS employ a null hypothesis of unit root test simillar to the ADF with the following specification

$$
y_{i t}=\rho_{i} y_{i t-1}+\sum \beta_{i j} \Delta y_{i t-j}+\delta x_{i t}+\varepsilon_{i t} \ldots \ldots 3.25
$$

Where $y_{i t}$ is the series being tested while $x_{i t}$ are the exogeneous variables representing bank specific and individual time trends and $\varepsilon_{i t}$ are the error terms assumed to be 
mutually indepenent. The autoregressive parameter $\rho_{i}$ is estimated for each bank separately allowing for large degree of heterogeneity. Specifically, just like in the ADF the null hypothesis arising from equation 6.48 is that:

$$
H_{0}: \rho_{i}=0 \text { for all } i \text { vs. } H_{1}: \rho_{i}>0 \text { for some Banks ...... } 3.26
$$

The test statistic $\left(Z_{t_{-} b a r}\right)$ for this test is constructed by cross-section averaging of the individual t-statistics for the $\rho_{i}$. Rejection of the null hypothesis implies that a series is stationary.

\section{Panel Data Co-integration Test}

One key issue in econometrics associated with the presence of non-stationary time series is that the variables in question may have a long-run relationship among them or they are cointegrated. Hence, it has become standard that once non-stationarity is detected in the data there is need to check for existence of co-integration among the series. In this study, we utilise a panel data cointegration test developed Pedroni $(1999,2004)$. The Pedroni panel cointegration test is based on the following model:

$$
y_{i t}=\alpha_{i}+\sum_{j=1}^{T} \beta_{j, i} x_{j, i, t}+\varepsilon_{i, t} \ldots \ldots 3.27
$$

The long-run coefficients $\beta_{\mathrm{j}, \mathrm{i}}$ may be different across the Banks. We use the group mean panel version of the Pedroni test. The null hypothesis of this test assumes a unit root in the residuals of the cointegration regression, which implies absence of cointegration. The alternative hypothesis assumes a root less than one, but allows for different roots in different countries. We use three different types of test statistics: an ADF type which is similar to the ADF statistic used in uni-variate unit-root tests, a nonparametric Phillips-Perron (PP) version, and a version which is based directly on the autoregressive coefficient ( $\rho$-test).

\subsection{Data and estimation of measures of market power 3.3.1 Description of data}

The analysis in this study involves commercial bank lending rate, two monetary policy variables (the Interbank rate and 3-month TB rate), two bank specific variables and two measures of competition. The two bank specific variables such as capital adequacy ratio ( and the core asset ratio; and the measures of competition the lerner index or the $\mathrm{HHI}$. The Lerner Index and $\mathrm{HHI}$ are estimated using procedures outlined in sub-section 3.3.2.

The study utilises bank-specific data covering the period from Q1 1998 to Q2 2015 obtained from prudential returns of chartered commercial banks operating in Zambia. The prudential database covers a range of variables from commercial bank balance sheets as reported to the Bank of Zambia. To obtain a balanced panel dataset, we exclude from the sample all banks whose operations commenced later than quarter 1 of 1998 or where the series are otherwise incomplete which left us with 13 commercial banks. 


\subsubsection{Estimating Measures of Market Power}

In this study, two measures of market power are used; HHI and Lerner Index. To estimate the quarterly $\mathrm{HHI}$, bank level balance sheet data for the period Q1 1998 to Q2 2015 is utilised. The study uses total assets of each bank to calculate market shares and then use these shares to estimate the $\mathrm{HHI}$ by summing up the squares of the shares.

On the other hand, the Lerner index is constructed for each bank and each quarter as follows;

$$
\text { Lerner }_{i t}=\frac{P_{i t}-M C_{i t}}{P_{i t}} \ldots \ldots \ldots \ldots \ldots . . . \ldots .28
$$

where $P_{i t}$ is the price of the banki's output and $M C_{i t}$ is the marginal cost. We computed $P_{i t}$, as the ratio of the total operating income (interest and non-interest revenues) to the total assets. Furthermore $M C_{i t}$ is derived from a standard translog cost function with a single aggregate bank output (namely, the total assets) and three input prices (fixed assets, labor, and borrowed funds). As was discussed in chapter four, the Lerner index has the advantage of capturing the impact of the pricing power on the asset and funding sides of the banks.

To estimate the Lerner Index, the study utilises and adapts a method employed by Simpasa (2013) to analyse competition in Zambia's banking sector. The method uses an estimate of the marginal cost using a trans-log cost function estimated with three inputs namely Labour, fixed assets, and borrowed funds and one output total assets. Specifically, the trans-log function estimated is as follows:

$$
\begin{aligned}
\ln T C_{i t}=\beta_{0}+ & \beta_{1} \ln Y_{i t}+\frac{1}{2} \beta_{2}\left(\ln Y_{i t}\right)^{2}+\beta_{3} \ln w_{i L t}+\beta_{4} \ln w_{i K t}+\beta_{5} \ln w_{i B t}+\frac{1}{2} \beta_{6}\left(\ln w_{i L t}\right)^{2} \\
& +\beta_{7}\left(\ln w_{i K t}\right)^{2}+\beta_{8} \ln w_{i L t} * \ln Y_{i t}+\beta_{9} \ln w_{i K t} * \ln Y_{i t}+\varepsilon \ldots \ldots \ldots .29
\end{aligned}
$$

$T C_{i t}$ is total operating costs (interest expenses plus non-interest expenses); output is measured by total assets $\left(Y_{i t}\right)$; $w_{i L t}$ is the price of labour measured as ratio of total labour costs to total assets; $w_{i B t}$ is the price of borrowed measured as ratio of total interest expenses to total borrowed funds; $w_{i K t}$ is the price of capital measured as ratio of total non-labour costs to fixed assets input factor prices are as defined above while $\varepsilon$ is a composite disturbance error term obeying all classical assumptions. Equation 3.29 above will be estimated using the pooled mean group procedure proposed by Pesaran et al $(1997,1999)$.

Using results from estimating 3.29, the bank specific marginal cost (MC) is estimated as in Simpasa (2013) using the formula:

$$
M C_{i t}=\frac{T C_{i t}}{Y_{i t}}\left[\beta_{1}+\beta_{2} \ln Y_{i t}+\beta_{8} \ln w_{i L t}+\beta_{9} \ln w_{i K t}\right] \ldots \ldots \ldots 3.30
$$


Using the $\mathrm{MC}$ equation above and the price of output (approximated by total operating income divided by total assets), the bank specific-time varying Lerner Index is estimated using the formula in 3.28 .

\subsection{Empirical Results}

In this section, empirical results on the effect of bank competition or concentration on the transmission of changes in monetary policy to retail rates are presented. The section starts with the presentation of a summary result of empirical estimates of market power and $\mathrm{HHI}$ using approaches outlined above and later uses these to evaluate the effect of competition on monetary policy.

\subsection{The Hirschman-Herfindahl Index (HHI)}

Table 1 present some statistics about the estimates of the HHI. It shows that average $\mathrm{HHI}$ over the sample period is 0.16 while the minimum and maximum is 0.11 and 0.24 , respectively. Furthermore, the Jarque-Bera statistic suggests that the $\mathrm{HHI}$ is heavily skewed to the right towards more concentration in the industry.

\section{Table 1: Summary statistics on the HHI estimates}

\begin{tabular}{|l|c|c|}
\hline & HHI & LERNER \\
\hline Mean & 0.161 & 0.255 \\
\hline Median & 0.150 & 0.289 \\
\hline Maximum & 0.238 & 0.699 \\
\hline Minimum & 0.118 & -0.161 \\
\hline Std. Dev. & 0.008 & 0.059 \\
\hline Skewness & 0.330 & 0.890 \\
\hline Kurtosis & 2.354 & 3.730 \\
\hline & & \\
\hline Jarque-Bera & 18.949 & 82.223 \\
\hline Probability & 0.000 & 0.000 \\
\hline & & 136.158 \\
\hline Sum & 69.876 & 35.590 \\
\hline Sum Sq. Dev. & 0.032 & \\
\hline & & 533 \\
\hline Observations & 533 & \\
\hline
\end{tabular}

Source: computations by the Author

\subsection{The Lerner Index}

The results from estimating equation 3.29 as well as the Hausman test are presented in table A1. The results of the Hausman Test for Panel estimation Justifies the use of the fixed effects model over the random effects model in estimating our trans-log total cost function. Results in table A1 provides parameter estimates that are reasonable 
and carry expected signs. The parameter estimates and equation 3.30 are then used to estimate bank specific-time varying marginal cost which is used to estimate the Lerner Index. Summary statistics of the estimated Lerner Index are presented in table 1 and figure $\mathrm{A} 1$ compares estimates of the $\mathrm{HHI}$ and Lerner Index. Table 1 shows that estimates of the Lerner Index averaged 0.26 similar to those found by Simpasa (2013) with an average of 0.27 and this difference could be attributed to the extension in dataset. Figure $\mathrm{A} 1$ shows that there is a positive relationship between the $\mathrm{HHI}$ and Lerner Index. Generally over the sample period both measures have been declining indicating that the banking sector may have become more competitive following the entry of new banks. Over this period six new banks have since started operating in Zambia thereby inducing incumbents to further cut prices to maintain their market share.

\subsection{Empirical Evidence of the effect of Bank Competition on Interest Rate Pass-through}

Here the two measures of competition ( $\mathrm{HHI}$ and Lerner Index) estimated in sections 4.1 and sections 4.2 are used to analyse the effect of bank competition on the interest rate pass-through in Zambia. In addition to the two measures our analysis include the bank specific lending rate as the dependent variable and 3-month TB and interbank rates as the monetary policy variables while the Capital adequacy Ratio and Liquidity Ratio are the bank specific variables.

\subsubsection{Results of Specification Tests}

\section{Panel Unit Root Test}

It has become a standard to check for the existence of non-stationarity in any dataset with time series characteristics such as panel data and univariate time series. This is because undertaking econometric analysis without taking into account non-stationarity would lead to spurious results (Engel and Granger, 1987). The present of unit roots in our panel data is checked using the test proposed by Im et al. (2003) as well as the Levin, Chin, Chu test (2000) for robustness sake.The panel unit root test results are presented in table 2 below. 
Table 2: Panel Unit Root Tests

\begin{tabular}{|c|c|c|c|c|c|c|}
\hline & \multicolumn{3}{|c|}{ IPS TEST } & \multicolumn{3}{|c|}{ LLC TEST } \\
\hline & \multicolumn{3}{|c|}{$\overline{1}^{\mathrm{st}}$} & \multicolumn{3}{|c|}{$7^{\text {st }}$} \\
\hline & Levels & Difference & Characteristic & Levels & Difference & Characteristic \\
\hline Average Lending rate & -0.25 & $-8.20^{* * *}$ & $\mathrm{I}(1)$ & 0.15 & $-7.59^{* * *}$ & $\mathrm{I}(1)$ \\
\hline 3-month TB rate & -0.62 & $-11.33^{\star * *}$ & $\mathrm{I}(1)$ & -0.16 & $-12.84^{\star * *}$ & $\mathrm{I}(1)$ \\
\hline Interbank Rate & $-4.20^{\star \star \star}$ & $-15.43^{* * *}$ & $\mathrm{I}(0)$ & $-6.93^{* * *}$ & $-17.80^{\star * *}$ & $\mathrm{I}(0)$ \\
\hline $\mathrm{HHI}$ & -0.26 & $-4.94^{* * *}$ & $\mathrm{I}(1)$ & 3.18 & $-3.78^{\star * \star}$ & $\mathrm{I}(1)$ \\
\hline Lerner Index & $-3.72^{\star \star \star}$ & $-15.52^{\star \star *}$ & $\mathrm{I}(0)$ & $-4.17^{\star \star \star}$ & $-9.94^{\star \star \star}$ & $\mathrm{I}(0)$ \\
\hline CAR & -1.27 & $-12.31^{* * *}$ & $\mathrm{I}(1)$ & -0.07 & $-6.61^{* * *}$ & $\mathrm{I}(1)$ \\
\hline Liquid Ratio & -0.69 & $-11.59^{\star * *}$ & $\mathrm{I}(1)$ & -0.05 & $-9.78^{* * *}$ & $\mathrm{I}(1)$ \\
\hline
\end{tabular}

Results from the two panel unit root tests show that all variables are integrated of order one, I(1) with an exception of the Interbank rate and the Lerner Index.

\section{Panel Co-integration Test}

Results from the panel unit root tests above showed that most of the variables being used in our study are integrated of order one I (1) and hence there is need to test for existence of co-integration among the variables. The results for Pedroni's three panel co-integration tests as applied to the long-run models of the average lending are presented in table 3 below:

Table 3: Pedroni Co-integration Test Results

\begin{tabular}{|c|c|c|c|}
\hline & \multicolumn{3}{|c|}{ Group Mean Panel Co-integration Tests } \\
\hline & Rho & PP & ADF \\
\hline Lending & & & \\
\hline Rate & $-2.46(0.007)^{\star * *}$ & $-3.23(0.001)^{\star * *}$ & $-1.55(0.051)^{*}$ \\
\hline
\end{tabular}

Results in table 3 indicate that the null-hypothesis of no co-integration can be rejected, indicating that there is co-integration among the variables in the sample. These results are similar to others such as Leuvenstein et al. (2006) who also find co-integration in a panel of euro area banks using a similar method. These results justify the use of a panel error correction model in our estimation.

\subsubsection{Regression Results}

Tables $4 a$ and $4 b$ as well as $B 1$ and $B 2$ in the appendix presents results of the effects of measures of market power on the interest rate pass-through in both short and long run. Table 4a gives results in which the $\mathrm{HHI}$ is a measure of market power while table $4 \mathrm{~b}$ provides results with the Lerner Index as measure of bank specific market power 
while the 3-month TB rate is the policy variable. Similarly table B1 provides results with $\mathrm{HHI}$ as measure of competition while table B2 provides results with Lerner index and the interbank rate as the policy variable.

Table 4a: The effect of Bank Concentration on Short and long Term Average Lending rates (3month TB rate)

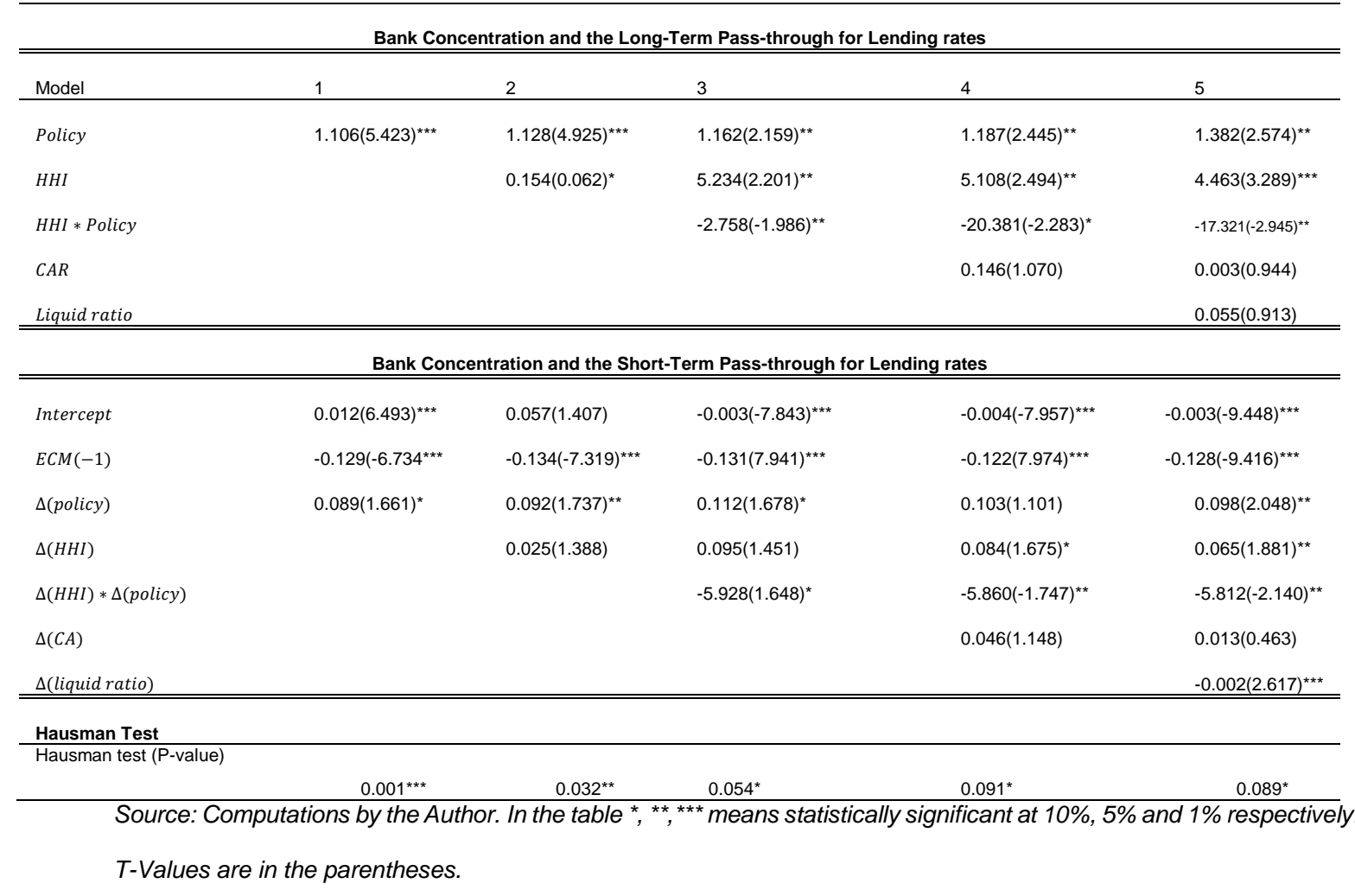

Top half of tables $4 a$ and $4 b$ as well as B1 and B2 in appendix B provide the log run results while bottom half provide short run results with an error correction term. The Hausman test results reported in table $4 a$ above indicate that the fixed effects estimation is more efficient than the random effects. Results in the top half of the tables indicate several striking findings. First results indicate that changes in the 3-month TB rate and interbank rate have significant effects on the average lending even after taking into account competition. Secondly, with an exception of model 2 in table $4 \mathrm{~b}$ the parameter estimate on a measure of competition has the correct significant positive sign indicating that banks in a less competitive environment tend to keep lending rates higher. This result is as expected from the theoretical framework as well as empirical evidence by others such as Leroy and Lucotte (2014) on the EU; Deriantino (2013) on Indonesia; and Brissimiss et al. (2014) on EU and USA. In addition, the above result (especially those in table 4a) supports the "Structure-Conduct-Performance" hypothesis which states that firms in a more concentrated or less competitive markets tend to charge higher prices. More importantly for this study is that there exists a negative significant interaction between policy variables and measures of market power in all models except model 4 in table $4 \mathrm{~b}$ and this effect still remains significant 
even after taking into account bank specific characteristics. This is similar to findings by others such as Leroy and Lucotte (2014) and implies that less competitive or more concentrated banking system hinders the effectiveness of monetary policy transmission or the interest rate pass-through. In other words, banks with greater market power or operating in concentrated markets tend to respond less to monetary policy shocks. In a nutshell, the above analysis of the results findings support our theoretical model which showed that competitive banks or banks in less concentrated markets are more responsive to monetary policy changes.

Table 4b: The effect of Bank Competition on Short and Long Run Average Lending rates (3-month TB rate)

\begin{tabular}{|c|c|c|c|c|c|}
\hline \multicolumn{6}{|c|}{ Bank Competition and the Long-Term Pass-through for Lending rates } \\
\hline Model & 1 & 2 & 3 & 4 & 5 \\
\hline Policy & $1.106(5.423)^{\star \star *}$ & $1.162(5.526)^{\star \star *}$ & $0.957(3.532)^{\star \star *}$ & $0.954(3.454)^{\star \star *}$ & $1.025(6.837)^{\star \star *}$ \\
\hline Lerner & & $0.057(0.796)$ & $0.148(1.744)^{\star \star}$ & $0.146(1.672)^{*}$ & $0.189(1.656)^{*}$ \\
\hline Lerner $*$ Policy & & & $-1.230(-1.643)^{*}$ & $-0.998(-1.505)$ & $-1.586(-1.957)^{\star}$ \\
\hline CAR & & & & $0.001(0.889)$ & $0.001(2.916)^{\star *}$ \\
\hline Liquid ratio & & & & & $-0.041(2.200)^{* *}$ \\
\hline \multicolumn{6}{|c|}{ Bank Competition and the Short-Term Pass-through for Lending rates } \\
\hline Intercept & $0.012(6.493)^{\star \star \star}$ & $0.013(6.775)^{\star \star \star}$ & $0.016(6.654)^{\star \star \star}$ & $0.016(6.407)^{\star * *}$ & $0.021(4.474)^{\star \star \star}$ \\
\hline $\operatorname{ECM}(-1)$ & $-0.129(-6.743)^{\star \star *}$ & $-0.124\left(-6.677^{\star \star *}\right.$ & $-0.125(-6.856)^{* \star *}$ & $-0.123(-6.792)^{\star * *}$ & $-0.133(-5.967)^{\star * *}$ \\
\hline$\Delta($ policy $)$ & $0.089(1.661)^{\star}$ & $0.089(1.753)^{*}$ & $0.023(0.878)$ & $0.026(0.862)$ & $0.044(2.668)^{* \star *}$ \\
\hline$\Delta$ Lerner) & & $0.012(1.924)^{\star}$ & $0.027(1.787)^{\star}$ & $0.019(0.792)$ & $0.014(1.636)^{*}$ \\
\hline$\Delta($ Policy $) * \Delta($ Lerner $)$ & & & $-0.956(2.146)^{\star \star}$ & $-0.961(-0.783)$ & $-1.210(1.901)^{*}$ \\
\hline$\Delta(C A)$ & & & & $0.010(1.678)^{*}$ & $0.013(3.224)^{\star \star}$ \\
\hline$\Delta$ (liquid ratio) & & & & & $-0.004(-1.868)^{\star}$ \\
\hline
\end{tabular}

Source: Computations by the Author. In the table *, ${ }^{* *},{ }^{* * *}$ means statistically significant at $10 \%, 5 \%$ and $1 \%$ respectively. $T$ -

Values are in the parentheses.

The bottom halves of tables $4 \mathrm{a}$ and $4 \mathrm{~b}$ as well as those in appendix $B$ provides results for the effect of competition or concentration on commercial bank lending rates' short term adjustment. Firstly the results show a very significant negative sign for the errorcorrection term for all our models which is an indication that there is an adjustment towards equilibrium every time there is shock disequilibrium among the variables. In addition, we find mixed results regarding the response of lending rates to policy rate changes. However, we need to note that in most cases the estimated coefficient have the correct positive sign.

The estimated coefficients help to decipher the effects of competition on short run interest rate pass-through. As predicted by the theoretical model results presented in tables $4 \mathrm{a}$ and $4 \mathrm{~b}$, the coefficient on the policy (interbank rate and 3-month TB rate) variable is positive and significant in most cases suggesting that tight monetary leads to an increase in lending rates. Specifically, the results suggest that following a $10 \%$ increase in the 3-month TB rate commercial bank lending rates will increase by $0.2-$ 
$1.12 \%$ immediately while a similar increase in the interbank rate suggest that lending rates will increase by $0.07-1.07 \%$. Furthermore, the interaction term between the policy variables and measures of competition $(\mathrm{HHI}$ and Lerner Index) are negative and significant in most cases suggesting that reduced competition in the banking system dampens the response of banks to monetary policy. It is also important to note that accounting for firm specific factors such as capital adequacy ratio and liquid ratio does no change these findings.

\subsection{Conclusions}

This study investigates the effect of bank competition or lack of it on the transmission of monetary policy in Zambia, focussing in the interest rate pass-through. In addition, it investigated the effect of bank competition on the level of interest rates in Zambia. The study utilises panel data methods and two measures of competition $(\mathrm{HHI}$ and Lerner Index) on the interest rates. Given the analysis in this paper, we can draw the following conclusions:

a) In line with theory and predictions of the model developed in this paper, there is positive relationship between policy variables (interbank and 3-month TB rate) and commercial bank lending rate.

b) Increased competition helps to increase the response of bank lending rates to changes in monetary policy variables. These results indicate that improving the competitiveness of the financial sector could go a long way in improving the effectiveness of monetary policy in Zambia and other developing economies.

c) Reduced competition or increased concentration increases the commercial bank lending rates. This result is important especially in explaining why commercial bank lending rates in developing countries have remained high despite falling default rates and inflation following economic and financial reforms that started in the 1990s.

From a policy perspective, these results imply that there is need for more financial reforms aimed at enhancing competition in the banking sector in order to lower lending rates as well as enhancing monetary policy effectiveness. 


\section{APPENDIX A}

Table A1: Fixed Effects Panel Estimation of the Total Cost Function

\begin{tabular}{|c|c|c|c|}
\hline \multicolumn{4}{|c|}{ Dependent Variable: $\operatorname{Ln}(T C)$} \\
\hline Independent Variables & Coefficient & T-Statistic & P-Value \\
\hline Intercept & 0.070 & 0.167 & 0.868 \\
\hline $\ln \left(w_{l}\right)$ & 0.553 & 5.773 & $0.000 * * *$ \\
\hline $\ln \left(w_{K}\right)$ & 0.086 & 1.857 & $0.048 * *$ \\
\hline $\log ($ assets $)$ & 0.974 & 17.465 & $0.000 * * *$ \\
\hline$\frac{1}{2}(\ln (\text { assets }))^{2}$ & -0.002 & -4.190 & $0.000 * * *$ \\
\hline$\frac{1}{2}\left(\ln \left(w_{l}\right)\right)^{2}$ & 0.015 & 1.295 & 0.196 \\
\hline$\frac{1}{2}\left(\ln \left(w_{K}\right)\right)^{2}$ & 0.042 & 3.117 & $0.002 * * *$ \\
\hline $\ln \left(w_{K}\right) * \ln \left(w_{l}\right)$ & -0.064 & -4.192 & $0.000 * * *$ \\
\hline $\ln ($ assets $) * \ln \left(w_{l}\right)$ & 0.033 & 4.452 & $0.000 * * *$ \\
\hline $\ln ($ assets $) * \ln \left(w_{K}\right)$ & 0.010 & 1.086 & 0.278 \\
\hline Risk & 0.204 & 5.746 & $0.000 * * *$ \\
\hline \multicolumn{4}{|c|}{ Diagnostics } \\
\hline Hausman test $(P-$ value $)$ & & $0.030 * *$ & \\
\hline$\rho$ & & 0.783 & \\
\hline$\sigma_{u}$ & & 0.273 & \\
\hline$\sigma_{\varepsilon}$ & & 0.138 & \\
\hline$R^{2}$ & & 0.907 & \\
\hline No. of Observations & & 533 & \\
\hline$F-$ statistic $(P-$ value $)$ & & $0.000 * * *$ & \\
\hline
\end{tabular}

Significance Level: $* P<0.10 ; * * P<0.05 ; * * * P<0.001$

SOURCE: Author's Own Computations using BOZ data 
Figure A1: Evolution of the HHI and Lerner Index

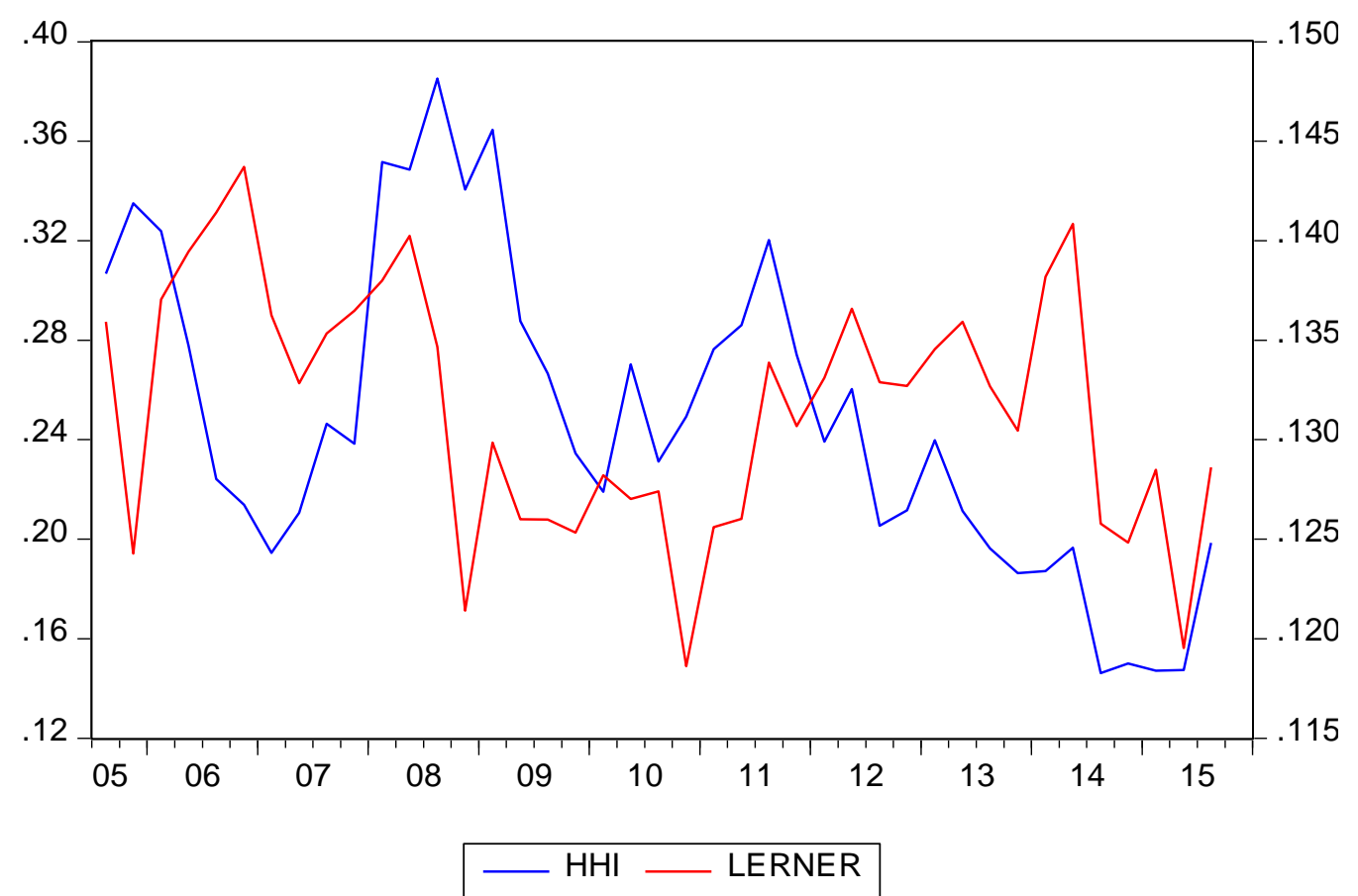

\section{APPENDIX B}

Table B1: The effect of Bank Concentration on Short and long Term Average Lending rates (Interbank Rate)

\begin{tabular}{|c|c|c|c|c|c|}
\hline \multicolumn{6}{|c|}{ Bank Concentration and the Long-Term Pass-through for Lending rates } \\
\hline Model & 1 & 2 & 3 & 4 & 5 \\
\hline Policy & $1.125(2.618)^{* \star *}$ & $1.135(2.702)^{\star \star \star}$ & $1.155(2.889)^{* \star \star}$ & $1.141(2.886)^{\star \star \star}$ & $1.194(3.228)^{\star \star \star}$ \\
\hline HHI & & $0.971(2.658)^{* \star \star}$ & $7.249(3.258)^{* \star *}$ & $7.718(3.249)^{* \star *}$ & $5.503(3.753)^{\star \star \star}$ \\
\hline HHI * Policy & & & $-17.995(-2.829)^{\star \star \star}$ & $-22.409(-2.836)^{\star \star \star}$ & $-34.576(-3.203)^{\star \star \star}$ \\
\hline CAR & & & & $0.002(1.496)$ & $0.001(1.492)$ \\
\hline Liquid ratio & & & & & $-0.050(2.551)^{* *}$ \\
\hline \multicolumn{6}{|c|}{ Bank Concentration and the Short-Term Pass-through for Lending rates } \\
\hline Intercept & $0.009(6.670)^{\star \star \star}$ & $-0.006(-5.421)^{\star \star \star}$ & $-0.121(-8.251)^{\star \star \star}$ & $-0.127(-8.183)^{\star \star \star}$ & $-0.092(-9.235)^{\star \star \star}$ \\
\hline $\operatorname{ECM}(-1)$ & $-0.131(-6.873)^{\star \star \star}$ & $-0.135(-8.073)^{\star \star \star}$ & $-0.137(-8.231)^{\star \star \star}$ & $-0.136(-8.220)^{\star \star \star}$ & $-0.155)-9.330)^{\star \star \star}$ \\
\hline$\Delta($ policy $)$ & $0.069(1.429)$ & $0.107(2.712)^{\star \star \star *}$ & $0.021(1.662)^{\star}$ & $0.011(1.651)^{\star}$ & $0.093(1.672)^{\star}$ \\
\hline$\Delta(H H I)$ & & $0.242(1.404)$ & $0.240(1.720)^{*}$ & $0.271(1.870)^{\star *}$ & $0.571(1.482)$ \\
\hline$\Delta(H H I) * \Delta($ policy $)$ & & & $-0.441(-1.909)^{*}$ & $-0.646(-1.867)^{* *}$ & $-2.917(-1.745)^{*}$ \\
\hline$\Delta(C A)$ & & & & $0.008(0.806)$ & $0.008(0.968)$ \\
\hline$\Delta$ (liquid ratio) & & & & & $-0.012(-1.338)$ \\
\hline
\end{tabular}


Table B2: The effect of Bank Competition on Short and Long Run Average Lending rates (Interbank Rate)

\begin{tabular}{|c|c|c|c|c|c|}
\hline Model & 1 & 2 & 3 & 4 & 5 \\
\hline Lerner & & $0.062(1.693)^{\star}$ & $0.142(1.672)^{\star}$ & $0.163(1.657)^{*}$ & $0.103(7.358)^{\star * \star}$ \\
\hline Lerner $*$ Policy & & & $-0.944(1.382)$ & $-0.960(-1.647)^{\star}$ & $-1.421(1.895)^{\star \star}$ \\
\hline Liquid ratio & & & & & $-0.050(16.960)^{\star \star \star}$ \\
\hline \multicolumn{6}{|c|}{ Bank Competition and the Short-Term Pass-through for Lending rates } \\
\hline Intercept & $0.009(6.670)^{\star \star \star}$ & $0.010(7.119)^{\star \star \star}$ & $0.013(7.290)^{\star \star *}$ & $0.014(7.288)^{\star \star \star}$ & $0.019(1.093)$ \\
\hline LLerner) & & $-0.013(1.943)^{*}$ & $-0.021(1.131)$ & $0.017(1.812)^{*}$ & $0.019(2.023)^{\star \star}$ \\
\hline$\Delta($ Policy $) * \Delta($ Lerner $)$ & & & $-1.072(1.701)^{*}$ & $-1.047(-1.73)^{*}$ & $-1.006(-1.371)$ \\
\hline$\Delta(C A)$ & & & & $-0.009(1.726)^{*}$ & $0.010(1.566)$ \\
\hline
\end{tabular}

$\Delta$ (liquid ratio) Source: Computations by the Author. In the table *, ${ }^{\star *},{ }^{\star * *}$ means statistically significant at $10 \%, 5 \%$ and $1 \%$, respectively. TValues are in the parentheses. 


\section{References}

Adams, R.M. and Amel, F. (2005), "The effects of local banking market structure on the banking lending channel of monetary policy". A paper presented at the ASSA convention of 2005: Available at http://www.federalreserve.gov/pubs/feds/2005/200516/200516pap.pdf

Bikker, J. and Haaf, K. (2002), "Competition, concentration and their relationship: an empirical analysis of the banking industry", Journal of Banking and Finance, vol. 26 (11), 2191-2214.

Blei, S. (2007), "On the Relevance of Credit Market Structure to Monetary Policy", FRB of St. Louis working paper no 2007/03.

Bresnahan, T. (1982), "The Oligopoly solution concept is identified", Economics Letters, vol. 10, 87- 92.

Brismiss, S. and Delis, M. (2013), "Bank Heterogeneity and Monetary Policy Transmission", ECB working paper no. 12133/2010. Available online at http://www.ecb.europa.eu/pub/pdf/scpwps/ecbwp1233.pdf

Boone, J. (2008), "A new way to measure competition”, Economic Journal, Vol. 118(531), 1245-1261.

Bramer, P., Gischer, H., Richter, T., and WeiB M. (2012), "Diverse Degrees of Competition within EMU and their Implications for Monetary Policy", Faculty of Economics and Management Working Paper no. 10/2012

Church, J. and Ware, R. (2009). Industrial Organisation: A strategic Approach. Irwin Mcgraw-Hill,USA

Deriantino, E. (2009), "Banking Competition and Effectiveness of Monetary Policy Transmission: A theoretical and Empirical Assessment on Indonesia". International Journal of Economic Sciences, vol. 12(3), 21-35.

Engle, R. F. and Granger, C. W. J. (1987), "Co-integration and error correction: Representation, estimation and testing", Econometrica vol. 55, 251-76.

Evanoff, D. and Fortier, D. (1988), "Re-evaluation of the structure- conduct performance paradigm in banking", . Journal of Financial Services Research, vol. 1(3), 2777-294.

Fungacova, Z., Solanko, L., Weill, L. (2013), "Does bank competition influence the lending channel in the euro area"? BOFIT discussion papers no. 17/2013: Bank of Finland.

Greene, William H. (2012). Econometric Analysis $7^{\text {th }}$ ed., Pearson, Boston.

Hadri, K. (2000), "Testing for stationary in heterogeneous panel data", Econometrics Journal, vol.3, 148-161.

Hausman, J. (1978), "Specification Tests in Econometrics”, Econometrica, Vol.46(2), 1251-1271.

Im, K. S.,.Pesaran, M. H and Shin, Y. (2003), "Testing for unit roots in heterogeneous Panels", Journal of Econometrics, Vol. 115, 53-74.

Lau, L. (1982), "On identifying the degree of competitiveness from industry price and output data", Economics Letters, Vol.10, 93-99. 
Lerner, A.P. (1934), "The concept of monopoly and the measurement of monopoly power", The Review of Economic Studies, Vol. 1(3), 157-175.

Leroy A., and Lucotte, Y. (2014), "Heterogeneous Monetary Policy Transmission Process in the Eurozone; Does Banking Competition Matter"? NBP working Paper 171/2014.

Leuwenstein, M., Sorensen, C., Biker, J. and Van Rixtel. (2006), "Impact of bank competition on the Interest Rate Pass-Through in the Euro Area", ECB Working paper 885/2006.

Mangwengwende, T., Chinzara, Z., and Nel, H. (2011), "Bank Concentration and the Interest rate passthrough in Sub-Saharan African", Rhodes University Economics Department WP no 233/2011.

Mier-y-Teran, Alfredo, (2012), "Bank Competition and the Transmission of Monetary Policy", A paper presented at a GEM Seminar at UCLA Anderson: Retrieved from http://www.alfredomieryteran.com.

Mishra, P., Montiel, P. and Spirimbergo, A. (2010) "Monetary Transmission in Low Income Countries", IMF working Paper series no. 10/2010.

Mojon, Benoit. (2000) "Financial Structure and the Interest Rate Channel of ECB Monetary Policy", ECB working paper no. 40/2000.

Ononugbo, M.C. (2012), "Monetary Policy in Developing Countries: The Case of Nigeria”, Unpublished PhD Dissertation, University of Leeds Business School.

Panzar, J. and Rosse, J. (1987), "Testing for "monopoly" equilibrium", The Journal of Industrial Economics, Vol. 35(4), 443-456.

Pedroni, P. (2000), "Critical values for co-integration tests in heterogeneous panels with multiple regressors", Oxford Bulletin of Economics and Statistics, Volume 61(S1), 653-670.

Pedroni, P. (2004), "Panel cointegration: asymptotic and finite sample properties of pooled time series tests with an application to the PPP hypothesis", Econometric Hypothesis, Vol. 20, 597-625.

Sander, H. and Kleimeier, S. (2004), "Interest Rate Pass-through in an Enlarged Europe: The Role of Banking Market Structure for Monetary Policy Transmission in Transition Countries", Research Memoranda 045, Maastricht: METEOR, Maastricht Research School of Economics of Technology and Organization.

Severe, S. (2011, "Monetary Policy issues Arising from Bank Competition". Unpublished PhD Dissertation, University of Oregon.

Sims, C. (1992), "Interpreting the macroeconomic time series facts: the effects of monetary policy", European Economic Review, vol. 36, 975-1001.

Tahir, M. N. (2012), "Relative Importance of Monetary Transmission Channels: A Structural Investigation; A case of Brazil, Chile and Korea”. University of Lyon Working paper Series. 